Johnson \& Wales University ScholarsArchive@JWU

MBA Faculty Conference Papers \& Journal Articles

Graduate Studies

$11-2010$

\title{
Developing A Culturally Responsive Classroom Collaborative Of Faculty, Students, And Institution
}

Paul J. Colbert

Johnson ఓ Wales University - Providence, pcolbert@jwu.edu

Follow this and additional works at: https://scholarsarchive.jwu.edu/mba_fac

Part of the Accounting Commons, Advertising and Promotion Management Commons, Agribusiness Commons, Business Administration, Management, and Operations Commons, Business and Corporate Communications Commons, Business Law, Public Responsibility, and Ethics Commons, Corporate Finance Commons, E-Commerce Commons, Entrepreneurial and $\underline{\text { Small Business Operations Commons, Finance and Financial Management Commons, Food and }}$ Beverage Management Commons, Gaming and Casino Operations Management Commons, $\underline{\text { Human }}$

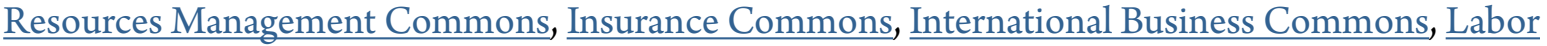
$\underline{\text { Relations Commons, Management Information Systems Commons, Management Sciences and }}$ Quantitative Methods Commons, Marketing Commons, Organizational Behavior and Theory Commons, Other Business Commons, Portfolio and Security Analysis Commons, Real Estate $\underline{\text { Commons, }} \underline{\text { Recreation Business Commons, Sales and Merchandising Commons, Strategic }}$ Management Policy Commons, Taxation Commons, Technology and Innovation Commons, and the Tourism and Travel Commons

\section{Repository Citation}

Colbert, Paul J., "Developing A Culturally Responsive Classroom Collaborative Of Faculty, Students, And Institution" (2010). MBA Faculty Conference Papers \& Journal Articles. 1.

https://scholarsarchive.jwu.edu/mba_fac/1

This Article is brought to you for free and open access by the Graduate Studies at ScholarsArchive@JWU. It has been accepted for inclusion in MBA Faculty Conference Papers \& Journal Articles by an authorized administrator of ScholarsArchive@JWU. For more information, please contact jcastel@jwu.edu. 


\title{
Developing A Culturally Responsive Classroom Collaborative Of Faculty, Students, And Institution
}

Paul J. Colbert, Johnson \& Wales University, USA

\begin{abstract}
Culture is integral to the learning process. It is the organization and way of life within the community of students and teachers and directs the way they communicate, interact, and approach teaching and learning. Although founded in particular values and principles, the academy, like most organizations, is impacted day-to-day by its culture. Yet, the traditional higher education institution has not been designed to operate within a racially or ethnically diverse student population. The social, political, economic, and cultural forces that support the institution influence the teaching and learning environments. To better address cultural diversity in the classroom, faculty must first examine their own cultural background and understand how biases may affect their interactions with students. To advance teaching and learning in the college classroom requires an understanding of the underlying values, beliefs, perceptions and assumptions of students, which affect their understanding of what they hear and read as well as how they express themselves in the classroom. When teachers recognize these different qualities, classroom instruction can be designed to connect content to students' backgrounds. This paper examines one approach to building a teaching and learning community through faculty professional development and collaboration. It provides an overview of a 5-part workshop series conducted for faculty at the Johnson \& Wales University Providence campus on intercultural learning and culturally responsive teaching. Focusing on the essential components of personalizing culture through the five institutions of family, school, religion, politics, and economics through workshop activities, it is an investigation of individual and institutional backgrounds to determine how faculty may recognize the forces that influence student behavior, and how to engage them in a more active learning process.
\end{abstract}

Keywords: active learning, cultural diversity, culturally responsive teaching, institutional culture, intercultural learning, socio-cultural consciousness

\section{INTRODUCTION}

\section{Cultural Identity}

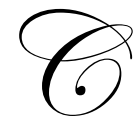

ulture is basically defined as a collaboration of shared meanings or common beliefs among an organization's members. Its founders have a significant influence in the development of the initial values and principles which tailor the fabric of the group, something that may not necessarily be apparent to newcomers to the organization and sometimes taken for granted by its seasoned members. A culture seeks an identity and strives to maintain its individuality and distinctiveness while recognizing the fibers that connect them to other cultures in more subtle ways.

This manuscript is re-printed in its entirety from the Contemporary Issues in Education Research, Volume 3, Number 9, September 2010. 
The roots of one's culture are considered the driving force behind how humans learn to behave (Harris, Moran \& Moran, 2004). The authors examined work culture from a global perspective and identified ten cultural characteristics that describe any group of people: (1) a sense of self or space; (2) communication and language; (3) dress and appearance; (4) food and feeding habits; (5) time and time consciousness, whether by time or age or status; (6) relationships; (7) values and norms defined by cultural needs; (8) beliefs and attitudes; (9) mental processing and learning defined by how people organize and process information; and (10) work habits and practices.

Chavez (2007) examined the teachings of four professors at a southwestern university in the U.S. to determine, from the student's perceptions, the level of congruency in providing appropriate learning experiences in a cross-cultural learning environment. Her findings point to six forces at work that are significant to empower or expand individual learning communities in higher education: (1) climate of safety, (2) spirit of risk-taking, (3) congruence, (4) pro-activity, (5) multiplicity, and (6) reciprocity. To varying extents, these elements were apparent in the learning communities studied. In these learning communities, teachers worked with all students to create collective, empowering learning experiences that utilized and honored multicultural realities within a shared and rigorous academic experience.

Villegas (2002) identified the teacher education institution as an important dimension in how we educate culturally responsive teachers. Institutions committed to preparing culturally responsive teachers and to diversifying the teaching force must acknowledge that colleges and universities, like elementary and secondary schools, were not traditionally designed to promote the value of diversity or to serve a racially/ethnically diverse student population.

Culturally responsive teachers are those who have a socio-cultural consciousness, have affirming view of the students from diverse backgrounds, have a sense that they are both responsible for and capable of bringing about educational change that will make schooling more responsive to students from diverse backgrounds, embrace constructivist views of teaching and learning, (active learning process), are familiar with their students' prior knowledge and beliefs, and design instruction that builds on what students already know while stretching them beyond the familiar (Villegas \& Lucas, xiv).

Hagberg (1998) focused on the true nature of the organizational culture and its assessment. He claimed that what many organizations claim to be their ideals is not always what they value and practice. A culture is the underpinning and the GPS of an organization, driving and steering its members, at a conscious and unconscious level, to behave in a certain way, as defined by the physical design of the organization, how the members dress, the organization's slogans, the language, the values stated, and the priorities that are identified. To understand one's culture can determine success or failure

In assessing culture, the question to be addressed is whether or not the existing culture supports and provides the necessary actions to reach its goals. When teaching problem identification in my graduate research courses, students must first identify if a gap exists in the current organization between what is and what should be; in other words, actual and the desired results. This assessment holds true for cultural identity. An organization must recognize its existing culture to determine what preliminary data gathering techniques are necessary to identify the gap and devise appropriate solutions to affect the desired changes.

Villegas and Lucas (2002) advocate that schools are a significant link to society and cannot be politically neutral. As institutions of society, (they) mirror the culture, language and values of those in power (p. xvii). How the governing group thinks, behaves and communicates constitutes the driving force in teaching and evaluation practices. The authors believe that although teachers may not be solely responsible for transforming an educational system, they are placed center-stage in achieving such transformation.

To adequately attend to cultural diversity in the classroom, teachers must look first at their own cultural background and understand how their personal biases affect their interactions with students. When teachers have knowledge of their biases and accept different cultural qualities, it is easier for them to recognize the creative ways that students express themselves. 
Socio-cultural consciousness (Figure 1) is the awareness that the way in which one sees the world is not universal, but is significantly molded by one's life experiences, tempered by such variables as race, ethnicity, social class and gender. Understanding that an individual's perspective of these variables is more a representation of personal experiences, and that they may not be shared by others, is a prerequisite for effective communication in a multicultural society (Villegas \& Lucas, 2002). On a continuum of socio-cultural consciousness or dysconsciousness, we mirror our personal experiences and views of the world in our teaching.

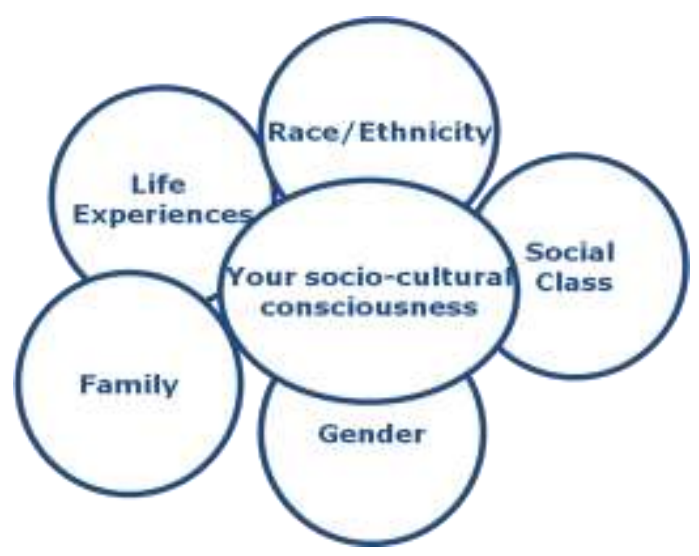

Figure 1: Socio-cultural Consciousness (adapted from Villegas \& Lucas, 2002)

\section{The JWU Culture}

An effective institutional culture demonstrates strong leadership. It is a collaborative process of stakeholders that provides rewards and achieves "buy-in". Basic assumptions, values, and norms drive the practices and behaviors of the institution.

The mission statement of Johnson \&Wales University (JWU) is "to empower its diverse student body to succeed by integrating general education professional skills and career-focused education." This follows the school of thought that the more people know about their own culture, the better they can address issues that surface while being cognizant of other cultures.

The university prepares students at the undergraduate and graduate levels for careers in business, education, and industry. Its purpose is "to assure that curricula, activities and services reflect the cultural diversity of the institution" reflecting a core value of "...fostering multiculturalism and providing an international educational experience."

The JWU MBA Hospitality and Global Leadership graduate program is comprised of 900+ students (70\% international, $30 \%$ domestic) with concentrations in global leadership, marketing, and finance. With such a large influx of international students, it is a continuous challenge for faculty, regardless of experience and education, to provide academic rigor and identify pedagogies that put theory into practical application.

\section{A Theoretical Framework of Culturally-responsive Teaching (CRT)}

Student-teacher interactions are taking place in an ever-increasing multicultural formal classroom setting. The mission of the CTEDL (Center for Teaching Excellence and Distance Learning) is to provide faculty-driven, faculty-focused programs to enhance and improve the teaching/learning process at the university. Its purpose is to identify best practices in teaching to illustrate that learning by example from demonstrated best practices is an effective way to understand the principles and the specifics of effective pedagogy. For the past several years, it has conducted a series of workshops at the JWU Providence campus that have focused on culture and its impact on 
teaching and learning. Full-time and adjunct faculty have been invited to attend the five-part series dedicated to an assessment of personal and institutional culture in a career-focused setting, using, as a framework, the five basic institutions that influence culturally responsive teaching; namely, family, religion, school, politics and economics.

The interactive workshops began with the following activity, an exercise culled from the archives of Irish Quakers working on identity and conflict resolution, which introduced faculty to how people may be grouped based on certain characteristics or perceptions. It required them to examine more closely how they may identify with and/or improve their socio-cultural awareness.

Faculty members were required to stand in linear fashion as one group and respond to the following:

\section{If you:}

- wear glasses

- have blue eyes

- $\quad$ are left-handed

- $\quad$ are less than $5 \mathrm{ft} .6$ in. tall

- drive a foreign-make car

- $\quad$ know the names of your students this year
Take:

2 steps back

1 step forward

3 steps back

1 step back

2 steps forward

4 steps forward

The initial exercise points out that differences come in many forms and that being a member of one particular group is not better or worse than being a member of another or several others, since one can be part of a number of groups. This led to break-up sessions to identify the positive aspects of acknowledging and appreciating diversity. The objective was to instill both a personal and professional awareness of differences in each other and its influences on how we communicate and interact with diverse groups in specific cultures and subcultures.

The first two workshops were dedicated to the tenets of culture from both a personal and professional perspective. Faculty were engaged in small heterogeneous groupings to first identify five groups with which each faculty member identified (Figure 2). This began the dialog of personal influences from early childhood that significantly influence who we are as individuals and as professional educators.

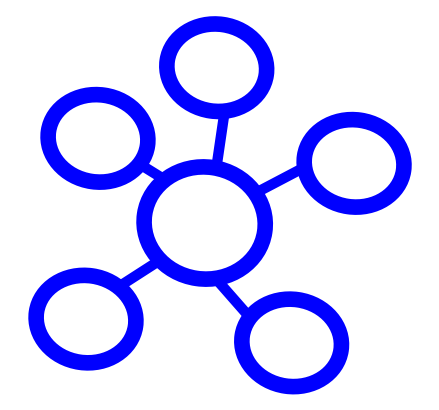

Directions:

1. Write your name in the center circle.

2. In the smaller circles, write the names of five groups with which you identify.

Think about a time when you felt very proud to be a member of a certain group circle.

Think about a time when it felt very painful to be a member of a certain group circle.

Acknowledging the dance of our lives in between or within these circles:

Some circles are created by:

$\begin{array}{lll}\text { Religion } & \text { Hobby/pastime } & \text { Geographic location } \\ \text { Race } & \text { Ethnic group/ country of origin } & \text { Neighborhood } \\ \text { Profession } & \text { Family role } & \text { Language } \\ \text { Workplace } & \text { Friendship } & \text { State of health } \\ \text { Physical appearance } & \text { Sexual orientation } & \text { Seeking help } \\ \text { Gender } & \text { College affiliation } & \text { Community service } \\ \text { Age } & \text { Political belief/ideology } & \end{array}$

Figure 2: Group Identification 
In sessions 2 and 3, faculty (with some new participants) were assigned to different groups from different schools on campus to focus on the five major social institutions that influence human behavior: (1) family; (2) religion; (3) school; (4) politics; and five economics. Each faculty member first addressed the questions (Table 1) in each of the five areas and reconvened with his/her group to share perceptions. The exercise triggered attitudes toward the dominant cultures and attitudes toward cultural diversity and culturally different students.

Table 1: Five Social Institutions of Influence

Family
What is your family background? (Ethnicity)
Was it an extended family? Did other family members help you with school?
What value did your family place on school?
Did your family play and active part in your school life, (participate in activities, fundraisers, sports, etc...)?
What was the economic status or your family?
Were other members of the family able to complete higher education?
Was/Is your family led by the matriarch or patriarch?
What holidays were celebrated in your household? Did they reflect values mirrored in your school?
Were any mentors or professionals involved in your educational choices?

\section{Religion}

Do you subscribe to a religion?

Is it a central part of your life or a peripheral one?

Did you attend a religious-based school or public school?

If religious, did the religious value system carry over in your choice of careers?

If public, did anything take the place of religious values in school?

How does religion "color" your presentation of information?

Was daily prayer a part of your school day?

If so, how did it affect your approach to the completion of required work?

Were there any imposed expectations with respect to religion that prompted you to work in school?

\section{School}

What was your family's attitude about school?

What was your school like? Large, small, public or private?

What kind of teachers did you have? Good ones, bad ones...

What was their approach to teaching?

How did you react to their style of teaching? How did this shape you?

Was your community close-knit, i.e. was the school a central part of your life?

Did you attend more than one elementary or secondary school? Were they different?

Did you feel powerful or powerless in school?

What is your reason for being a teacher?

Who or what experience led to your teaching career?

\section{Politics}

How was politics instrumental in your education?

Were laws and legislation key to your education, (Equal Opportunity, American Disabilities Act, etc.)?

Were your schools of high or low quality because of politics?

Did politics help or hinder your school attendance, (segregation or desegregation, war, etc.)?

\section{Economics}

How did your family economics affect your education?

How did local or national economics affect your education?

Can you understand the mindset of various communities and their economic limitations or excesses?

Did you develop expectations of others based on your familiarity with a certain lifestyle dependent on economics?

How does this affect your perception of success for these students?

Can economic disparities be used constructively in the classroom to engage students, foster creativity, and aid in the dissemination of information?

Can low income students be empowered by a desire that you foster as a teacher, to rise above their status in spite of its limitations?

Who holds the economic power? 
In sessions 3 and 4 the CTEDL posed the following question: Why assess our institutional culture?

The goals were to:

1. Determine the gap between the current and desired culture

2. Identify the possible need to change the culture while keeping core values intact

3. Better understand JWU subcultures and their impact on the institution's mission and values

Graduate and undergraduate faculty participants were asked to consider how JWU, as an educational institution, promotes multicultural practices. They were asked to identify whether there were reward systems in place for "good teaching" and if there were challenges to the traditional ways of teaching in the classroom. In addition they were asked to determine whether the "mavericks" push the envelope, fit in or get pushed out. An honest examination of the JWU culture requires faculty perceptions of what constitutes excellence in teaching and learning and whether our culture truly values such excellence in teaching and learning or is the mentality to "just teach it"? Because the Providence faculty is a diverse group in terms of experience and expertise, an inventory of the faculty behaviors and values important within the $\mathrm{J} \& \mathrm{~W}$ culture was considered, as well as an assessment of the personal and professional attributes that contribute to professional satisfaction and frustration. Finally, faculty were asked to describe a successful teacher in this environment.

The results were then compiled and discussed in session 5 of the workshop series. The non-empirical results (Table 2) indicated that, overall, faculty characterize JWU as a business institution that puts students first and prepares them for careers in a number of industries. Faculty, many of whom are content experts in their fields, see the University as community-oriented and collaborating with industry to help students succeed. Faculty see themselves as a dedicated teaching body devoted to providing skills and tools to succeed in the work world.

What they believe contributes to their satisfaction with the University is a collaboration among faculty who are provided flexibility and a sense of "entrepreneurship" in the classroom but who invite team work and a strong desire to improve the teaching and learning process. A high level of expectancy was considered both satisfactory and frustrating from an academic and administrative perspective, respectively. Demanding teaching schedules and committee work leaves inadequate time for student advising. Student apathy and lack of respect surfaced among most groups, particularly at the undergraduate level.

The general perception is that the University rewards faculty who demonstrate respect for and dedication to students. The more varied the teaching methods, the more students respond to the concepts presented. The University has a strong experiential component in the form of community service and a multicultural center and dedicates resources to developing a sense of community among its students.

Faculty consensus indicated that a successful teacher at JWU is one who is a knowledgeable professional, one who is affirming and embraces diversity, a flexible individual who enjoys being with students. On the negative side, some faculty recognized success in the form of high scoring student evaluations, indicating that too much value is placed on personality and popularity and not teaching.

\section{RECOMMENDATIONS}

The findings from the workshop series on individual and institutional perceptions of cultural identity at JWU indicated that the first step toward a culturally responsive teaching environment is awareness. Faculty and the University colleges in which they teach must be prepared to examine their pedagogical approaches to meet the needs of an increasing diverse student population and academic community. 
Table 2: Results of JWU Culture Perceptions

\begin{tabular}{|c|c|c|}
\hline $\begin{array}{l}\text { What } 10 \text { key words or } \\
\text { descriptive phrases } \\
\text { characterize J\&W's } \\
\text { culture? }\end{array}$ & $\begin{array}{ll}\text { - } & \text { Run like a business }(92 \%) \\
\text { - } & \text { Prepping for careers } \quad(94 \%) \\
\text { - } & \text { Preseriential } \\
\text { - } & \text { Students central to mission } \\
\text { - } & \text { Culture of community service } \\
\text { - } & \text { Practical experiences of faculty } \\
\text { - } & \text { "Second chance schools" } \\
\text { - } & \text { Celebration of diversity } \\
\text { - } & \text { Collaboration w/industry }\end{array}$ & \\
\hline $\begin{array}{l}\text { What faculty behaviors } \\
\text { and values are } \\
\text { important within the } \\
\text { J\&W culture? }\end{array}$ & $\begin{array}{ll}\text { - } & \text { Cheerfully doing what is required } \\
\text { - } & \text { Hard working: above and beyond (83\%) } \\
\text { - } & \text { Anti-intellectual behavior } \\
\text { - } & \text { Showing up: being there } \\
\text { - } & \text { Not complaining } \\
\text { - } & \text { Valuing practical information...not abstr } \\
\end{array}$ & \\
\hline $\begin{array}{l}\text { What personal and } \\
\text { professional attributes } \\
\text { contribute to your } \\
\text { satisfaction and/or } \\
\text { frustration within the } \\
\text { J\&W culture? }\end{array}$ & $\begin{array}{ll}\text { Satisfying } \\
& \text { Willingness to share }(88 \%) \\
\text { - } & \text { Flexible } \\
\text { - } & \text { Teatimistic } \\
\text { - } & \text { Autonomork } \\
\text { - } & \text { Entrepreneurial } \\
\text { - } & \text { "Go with flow" } \\
\text { - } & \text { Collegial environment } \\
\text { - } & \text { High level of expectancy } \\
\text { - } & \text { Loyal to J\&W } \\
\text { - } & \text { Sense of humor } \\
\text { - } & \text { Industry experience } \\
\text { - } & \text { Desire to improve teaching \& learning } \\
\text { - } & \text { "Like our students" } \\
\end{array}$ & $\begin{array}{ll} & \text { Frustrating } \\
\text { - } & \text { Lack of intellectualism in environment }(76 \%) \\
\text { - } & \text { Need for self-satisfaction } \\
\text { - } & \text { Student apathy } \\
\text { - } & \text { High of respect from students } \\
& \text { High expectancy }\end{array}$ \\
\hline $\begin{array}{l}\text { What teaching and } \\
\text { learning behaviors are } \\
\text { rewarded? }\end{array}$ & $\begin{array}{l}\text { Teaching and learning behaviors } \\
\text { (teacher/student): } \\
\text { - } \quad \text { Respectful to students }(93 \%) \\
\text { - } \quad \text { Patient with students } \\
\text { - } \quad \text { Vositive reinforcement } \\
\text { - } \quad \text { Training of teaching methods } \\
\text { - } \quad \text { Professional development activities } \\
\text { - } \quad \text { Community service participation } \\
\text { - } \quad \text { Vision Point 3: Teaching Excellence } \\
\text { - } \quad \text { Extra tutoring } \\
\text { - } \quad \text { Flexibility } \\
\text { - } \quad \text { Teacher of the Year }\end{array}$ & $\begin{array}{l}\text { Specific learning behaviors (student): } \\
\text { - } \quad \text { Memorization } \\
\text { - } \quad \text { Punctuality } \\
\text { Pleasant behavior }\end{array}$ \\
\hline $\begin{array}{l}\text { Characterize a } \\
\text { successful teacher in } \\
\text { this culture }\end{array}$ & $\begin{array}{ll}- & \text { Knowledgeable in subject matter (91\%) } \\
\text { - } & \text { Caring professional }(88 \%) \\
\text { - } & \text { Practical-minded } \\
\text { - } & \text { Eviden thanked by student(s) } \\
\text { - } & \text { Consistently dedicated and hard-working } \\
\text { - } & \text { Embraces diversity (72\%) } \\
\text { - } & \text { Really "likes" students } \\
\text { - } & \text { Being "parental" } \\
\text { - } & \text { High scores on student evaluations } \\
& \text { Flexible } \\
\end{array}$ & \\
\hline
\end{tabular}


Developing an affirming attitude towards students with culturally diverse backgrounds is the second step. Culturally responsive teaching requires attitude adjustment. Faculty attitudes towards students significantly shape expectations for learning. Culturally sensitive teachers recognize that culture is not only central to learning but that cultural conventions affect the approach to teaching and the student's approach to learning. Ignoring these differences tips the scales in favor of the "mainstream" and alienates others. Based on the deficit theory perspective that thinking, talking, and behaving differently from the norm (dominant) culture is inferior, then the teacher with a deficit approach towards culturally different students will tend to emphasize what these students lack and consequently reaffirm negative attitudes towards cultural differences. An affirming teacher is one who has examined his/her beliefs about students whose cultural backgrounds differ from the norm and tend to support these differences.

For the graduate school community I have identified specific teaching strategies to share with faculty, many of whom have classrooms composed of $75 \%$ international and $25 \%$ domestic students. Essential to this classroom is a positive environment where students feel trusted and respected. In most academic institutions, international students entering the classroom are immediately challenged by the native language. Attempting to familiarize themselves with American speech and tongue is difficult and requires a faculty member to recognize an elementary but critical component: enunciate clearly the material that is being presented.

For many students, main concepts and ideas may need to be repeated. Providing visual aids support the material and aid international students, in particular, in processing the information. Using PowerPoint slides with handouts in skeletal form provide an active learning forum that involves students in the learning. The use of e-mail and public folders serves many purposes and has become a staple for communicating class requirements and course expectations. International students rely heavily on these resource tools for review and updates and feel connected to the professor.

Proofreading your written work is imperative. Typographical errors or misspellings wreak havoc for the non-native speaking students. They may assume that the typo or misspelled word is a legitimate English word and they will spend inordinate amounts of time trying to decipher the meaning.

Reading and written assignments should be provided well in advance so that international students, in particular, may process the content in a more manageable and timely fashion. In research classes, for example, students are given a pre-class written assignment before the courses commence so that they can purchase the text and begin the readings, access class materials online, and come to class prepared to discuss expectations and participate in the class. A preliminary inventory is distributed via e-mail to each registered student in the class to determine a profile of his/her background, origin, special skills and specific goals and objectives for the course.

Many international students are less vocal in front of peers than domestic students. Since, in some cultures, this may be viewed as disruptive to the instructor and the classroom, the tendency to ask questions or volunteer information may be less than anticipated. For these students, their level of participation will not be the same as that of US students. International students are more comfortable participating in small group work than in whole class dialogue. At the graduate school we spend time reviewing the importance of team dynamics and how productivity requires input from each member into the discussion and the final product. This requires appointing one student on each team as facilitator to coordinate group efforts and ascertain that each team member understands both the requirements and the necessity to add voice to the dialog.

In the United States the interpretation and expectation of appropriate citation and referencing differs from that of many cultures. What we label cheating and plagiarism may occur when the international student had no real intention of being dishonest (Rees-Miller, n.d.). Through the Graduate School Professional Communications Center (PCC) and faculty who teach Communications and Research classes (core courses for all students), the importance and significance of proper citation and documentation is taught and demonstrated by example.

Cooperative and team learning has become a mainstay in the graduate classroom. It is the instructional use of small groups where students collaborate to reach individual potential to learn and engage in team dynamics. With a mix of international and domestic students, faculty have found collaborative learning to have strong and consistent positive effects on relationships between culturally-diverse students and team members become increasingly aware 
of cultural differences and more accepting of them. Not only does it highlight differences but provides a vehicle for sharing similar approaches to solving problems and interpret them from varied perspectives.

Active learning is a process that allows both faculty and students to determine what learning takes place in the graduate classroom. The use of questioning techniques involves students and allows them the opportunity to respond in a way that reflects their cultural diversity and that will expose their fellow students to those differences (Evans, 1991). Putting theory into practice affords a shared responsibility for classroom learning. I teach Research and Analysis to MBA graduate students and provide opportunities for conducting applied research in an area of global interest for both individuals and teams. International students, particularly from an Asian or Indian heritage, usually provide a cultural spin on the research data-gathering techniques.

An effective collaboration for the formal classroom requires commitment from the institution, the faculty and the students. In its mission statement an institution should clearly identify its support for diversity in curriculum, services, and activities. It must put into action what it defines on paper and provide a curriculum that meets the needs of a global market, resources to nurture collaborative between colleges in the university system, and faculty committed to meeting both professional and student needs. An institution's culture is a multicultural academic community and needs the support and involvement of its administration to serve its increasingly diverse student population.

It is further recommended that a longitudinal study be conducted focusing on the impact of culturally responsive teaching methodologies on learning at the graduate level to determine from an empirical perspective how culturally responsive teaching impacts student success in the college classroom environment.

\section{AUTHOR INFORMATION}

Dr. Paul J. Colbert is a faculty member at Johnson \& Wales University, Providence, RI where he is a professor of Research in the MBA program. He serves as Chair, Faculty Professional Development and was Director, Center for Teaching Excellence designing programs in teaching and learning and use and application of technologies. His research interests include active learning in higher education and its impact on the scholarship of teaching and learning. He is engaged in a book proposal on professional faculty development.

\section{REFERENCES}

1. Chavez, A.F. (2007). Islands of empowerment: Facilitating multicultural learning communities in college. International Journal of Teaching and Learning in Higher Education, 19(3), 274-288.

2. Gay, G. (2000). Culturally responsive teaching: Theory, research \& practice. New York: Teachers College Press.

3. Hagberg, R. (1998) Telling the CEO his/her baby is ugly. Retrieved from: http://www.leadervalues.com/Content/detailPrint.asp? ContentDetailID $=262$

4. Harris, P.R., Moran, R.T. \& Moran, S.V. (2004). Managing cultural differences: Global leadership strategies for the twenty-first century $\left(6^{\text {th }}\right.$ edition). Oxford, England: Elsevier Butterworth-Heinemann.

5. Kean, C., Campbell-Whatley, G.D. \& Richards, H.V. (2006). Becoming culturally responsive educators: Rethinking teacher education pedagogy. National Center for Culturally Responsive Educational Systems. Retrieved from: http://www.nccrest.org/Briefs/Teacher_Ed Brief.pdf

6. Kezar, A.J. \& Eckel, P.D. (2002, July/August). The effect of institutional culture on change strategies in higher education: Universal principles or culturally responsive concepts? The Journal of Higher Education, 73(4), 435-460.

7. Rees-Miller, J. (n.d.). Teaching international students: Some tips. Marietta College. Retrieved from: http://faculty.marietta.edu/intladvisory/docs/teaching tips.doc .

8. Rothstein-Fisch, C. \& Trumbull, E. (2008). Managing diverse classrooms: How to build on students' cultural strengths. Alexandria, VA: ASCD.

9. Trumbull, E. \& Pacheco, M. (2005). Leading with diversity: Cultural competencies for teacher preparation and professional development. The Education Alliance at Brown University: Providence, RI. 
10. Villegas, A. M. \& Lucas, T. (2002). Educating culturally responsive teachers. Albany, NY: State University of New York Press.

11. Wlodkowski, R.J. \& Ginsberg, M.B. (1995). Diversity and motivation: Culturally responsive teaching. San Francisco; Jossey-Bass.

\section{NOTES}

